University of Nebraska - Lincoln

DigitalCommons@University of Nebraska - Lincoln

Faculty Publications from the Harold W. Manter Laboratory of Parasitology

$12-1976$

\title{
Telorchis gutturosi sp. n. (Trematoda: Telorchiidae) from Graptemys pseudogeographica Gray in Nebraska, with Reports of Additional Species of Trematodes from Nebraska Turtles
}

\author{
Daniel R. Brooks \\ University of Toronto,dnlbrooks@gmail.com \\ Monte A. Mayes \\ University of Nebraska - Lincoln
}

Follow this and additional works at: https://digitalcommons.unl.edu/parasitologyfacpubs

Part of the Parasitology Commons

Brooks, Daniel R. and Mayes, Monte A., "Telorchis gutturosi sp. n. (Trematoda: Telorchiidae) from Graptemys pseudogeographica Gray in Nebraska, with Reports of Additional Species of Trematodes from Nebraska Turtles" (1976). Faculty Publications from the Harold W. Manter Laboratory of Parasitology. 212.

https://digitalcommons.unl.edu/parasitologyfacpubs/212

This Article is brought to you for free and open access by the Parasitology, Harold W. Manter Laboratory of at DigitalCommons@University of Nebraska - Lincoln. It has been accepted for inclusion in Faculty Publications from the Harold W. Manter Laboratory of Parasitology by an authorized administrator of DigitalCommons@University of Nebraska - Lincoln. 


\title{
TELORCHIS GUTTUROSI SP. N. (TREMATODA: TELORCHIIDAE) FROM GRAPTEMYS PSEUDOGEOGRAPHICA GRAY IN NEBRASKA, WITH REPORTS OF ADDITIONAL SPECIES OF TREMATODES FROM NEBRASKA TURTLES
}

\author{
Daniel R. Brooks \\ Gulf Coast Research Laboratory, P. O. Box A.G., Ocean Springs, Mississippi 39564 and \\ Monte A. Mayes \\ School of Life Sciences, University of Nebraska-Lincoln, and H. W. Manter Laboratory, \\ Division of Parasitology, University of Nebraska State Museum, Lincoln, Nebraska 68588
}

ABSTRACT: One species of digenean is described and 8 others reported from turtles in Nebraska. Telorchis gutturosi, described from Graptemys pseudogeographica, resembles T. stossichi, T. pseudoaculeatus, and T. pleroticus in having an acetabulum significantly smaller than the oral sucker, but differs by possessing a pharynx which is as large as the acetabulum and having the ovary only $1 / 10$ the body length from the acetabulum. Telorchis necturi is considered the senior synonym of T. cryptobranchi; Graptemys pseudogeographica is a new host. Hapalorhynchus stunkardi is reported for the first time since its description. Based on new morphological evidence, the generic diagnosis of Hapalorhynchus is emended and a key to the species provided. Spirorchis scripta, S. parvus, Protenes angustus, and Eustomos chelydrae are reported for the first time from Nebraska. Graptemys pseudogeographica is a new host for Heronimus mollis; Kinosternon flavescens is a new host for Telorchis corti.

Twenty-one species of platyhelminth parasites have been reported from Nebraska turtles (Brooks and Mayes, 1975). The present study reports seven additional species, one of which is described as new, and new hosts for two previously reported species.

Worms were removed from the host, flattened with slight coverslip pressure or not flattened (spirorchiids), fixed with AFA, stored in $70 \%$ ethanol, stained with Mayer's hematoxylin or Mayer's carmalum, and mounted in Canada balsam for study as whole mounts. Measurements are in micrometers unless otherwise stated; figures were drawn with the aid of a drawing tube.

\section{TELORCHIIDAE Stunkard 1924 \\ Telorchis gutturosi sp. $n$. (Figs. 1-3)}

Description (based on 9 complete and 1 partial specimens ): Body elongate, 3.72 to $4.27 \mathrm{~mm}$ long by 0.42 to $0.68 \mathrm{~mm}$ wide. Tegument with spines extending to level of acetabulum. Oral sucker subterminal, rounded, without lappets; 248 to 300 long by 240 to 324 wide. Prepharynx short; pharynx 120 to 132 long by 144 to 200 wide; cerebral ganglia conspicuous; esophagus 50 to 70 long; bifurcation 11 to $12 \%$ body length from anterior end, ceca extending to near posterior end of body.

Received for publication 3 February 1976.
Acetabulum weakly-developed, rounded, 136 to 172 long by 124 to 176 wide. Forebody 23 to $30 \%$ total body length. Ratio of sucker widths 1: 0.49 to 0.64 ; ratio of pharynx width to acetabulum width 1: 0.88 to 1.16 .

Testes spherical, tandem, contiguous, intercecal; 140 to 180 in diameter; posttesticular space equal to 11 to $13 \%$ body length. Cirrus sac 820 to 870 long, reaching level of posterior margin of ovary or slightly beyond, containing coiled seminal vesicle, prostatic cells, and eversible cirrus. Genital pore median, midway between acetabulum and bifurcation; genital atrium shallow.

Ovary 8 to $11 \%$ body length posterior to acetabulum, intercecal, amphitypic; ovoid; 108 to 160 long by 92 to 132 wide. Seminal receptacle small; Mehlis' gland and Laurer's canal present. Descending and ascending loops of uterus confined to intercecal space between anterior testis and ovary; space occupied by uterus 36 to $40 \%$ total body length; metraterm equal to $1 / 2$ length of cirrus sac. Vitelline follicles lateral, confined to extracecal space between level of anterior testis and midway between ovary and acetabulum. Eggs 36 to 40 long by 13 to 18 wide.

Excretory vesicle Y-shaped, bifurcation immediately postovarian; arms short, extending to anterior margin of ovary; excretory pore terminal.

Host: Graptemys pseudogeographica Gray, false map turtle ( 10 in 1 host).

Site: Small intestine.

Locality: Missouri River, 1.5 miles south of Brownville, Nebraska.

Holotype: USNM Helm Coll. No. 73522; paratypes: USNM Helm Coll. No. 73523; Univ. Neb, 

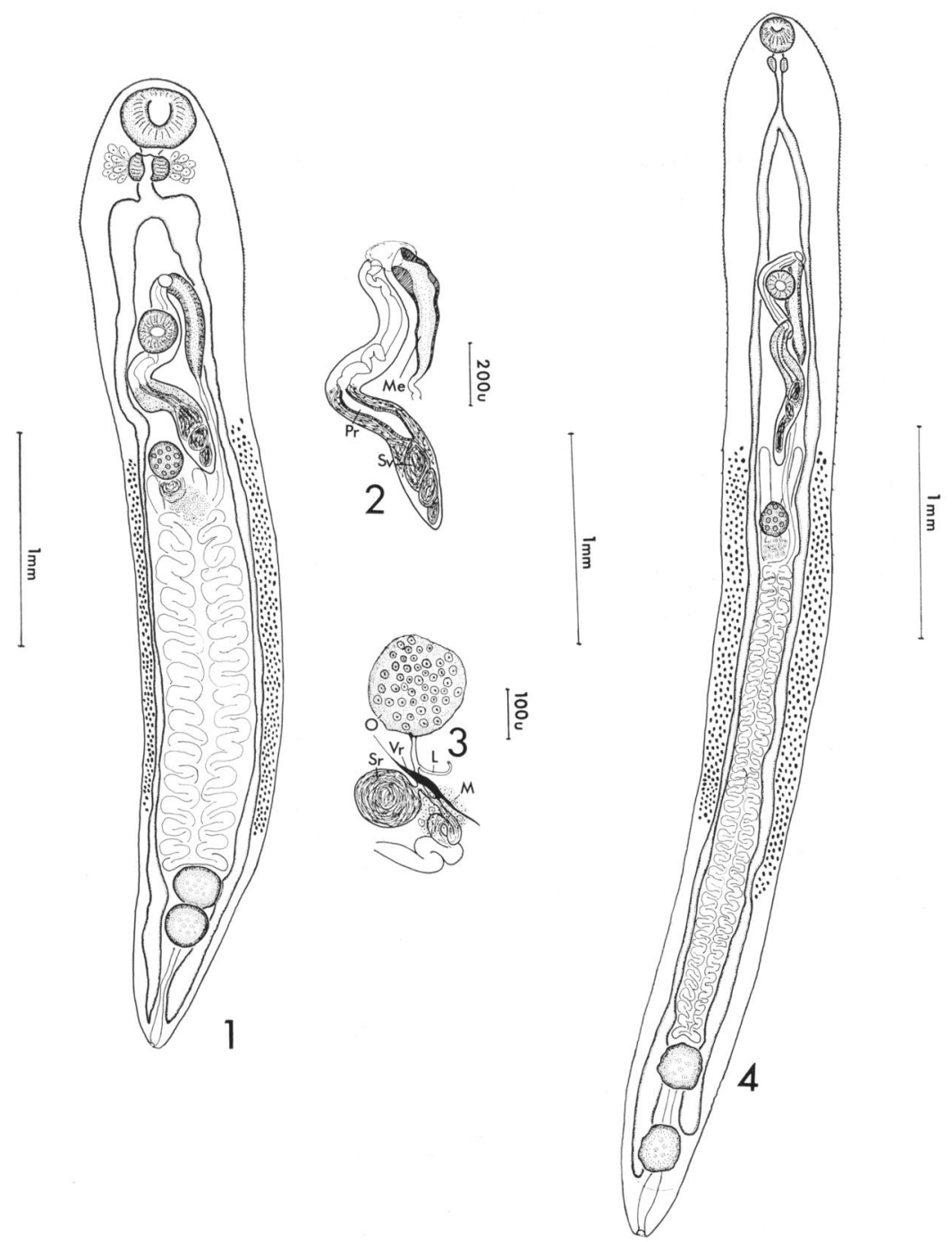

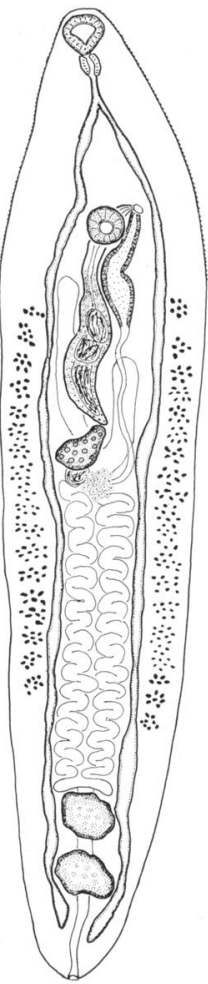

5

Figures 1-5. Trematodes from Nebraska turtles. 1-3. Telorchis gutturosi. 1. Holotype, ventral view. 2. Terminal genitalia, ventral view. 3. Ootype region, dorsal view. 4. Telorchis corti, ventral view. 5. Telorchis necturi, ventral view. Legend: $L=$ Laurer's canal; $M=$ Mehlis' gland; $\mathrm{Me}=$ Metraterm; $\mathrm{O}=$ Ovary; $\mathrm{Pr}=$ Prostatic complex; $\mathrm{Sr}=$ Seminal receptacle; $\mathrm{Sv}=$ Seminal vesicle; $\mathrm{Vr}=$ Vitelline reservoir.

State Mus., H. W. Manter Lab No. 20231, and in collections of authors.

Etymology: The specific name is Latin for "enlarged throat" used as a noun in the genitive singular and refers to the relative size of the pharynx.

Three previously described species of $\mathrm{Tel}$ orchis have an acetabulum significantly smaller than the oral sucker: T. pleroticus (Braun 1899) Wharton 1940; T. pseudoaculeatus Dollfus 1929; and T. stossichi Goldberger 1911. In all those species the pharynx is approximately half the size of the acetabulum, while the pharynx and acetabulum of $T$. gutturosi are subequal. The ovary of $T$. gutturosi is $1 / 10$ body length from the acetabulum; that of T. pleroticus is $1 / 6$ body length, and for T. stossichi and T. pseudoaculeatus $1 / 4$ body length. T. pleroticus further has a long prepharynx, no measurable esophagus, and a cirrus sac which does not reach the level of the ovary; T. pseudo- 
aculeatus has slightly larger eggs and a cirrus sac which does not reach the level of the ovary. The most similar species, T. stossichi, occurs in Europe, North Africa and Asia Minor in Emys orbicularia, a member of the same family (Emydidae) as Graptemys pseudogeographica.

\section{Telorchis necturi (Perkins 1928) Wharton 1940} (Fig. 5)

Synonym: Telorchis cryptobranchi McMullen and Roudabush 1935 new synonymy.

Host: Graptemys pseudogeographica (4 in 1 host), new host.

Site: Small intestine.

Specimens: 2, Univ. Neb. State Museum, H. W. Manter Lab. No. 20213.

The four specimens identified as T. necturi agree very closely with the original description by Perkins (1928). Telorchis necturi and T. cryptobranchi are distinguishable on the basis of a single attribute; $T$. necturi has a cirrus sac which terminates at the level of the posterior margin of the ovary, while the cirrus sac of $T$. cryptobranchi terminates immediately anterior to the ovary. Watertor (1967) clearly demonstrated that the posterior extent of the cirrus sac among members of Telorchis may be a plastic character and that minor differences in the extent of the cirrus sac are not sufficient grounds for recognizing a new species. The four specimens collected in this study have cirrus sac which terminate at varying points from immediately anterior to the ovary to the level of the posterior margin of the ovary, otherwise, they are indistinguishable. Therefore, $T$. necturi and T. cryptobranchi are considered synonymous.

\section{Telorchis corti Stunkard 1915 (Fig. 4)}

Host: Kinosternon flavescens Agassiz (7 in 1 host, new host.

Site: Small intestine.

Specimens: 2, Univ. Neb. State Mus., H. W. Manter Lab No. 20212.

Over 100 specimens of $T$. corti have now been collected from Chelydra serpentina, Chrysemys picta, and Trionyx spiniferus (Brooks and Mayes, 1975), Kinosternon flavescens (present report), and Thamnophis sirtalis (Brooks and Mayes, unpublished) in Nebraska. All specimens agree very closely with the original description; in no case does the cirrus sac terminate closer than one ovarian diameter anterior to the ovary.

\section{Protenes angustus (Stafford 1900) Ward 1918}

Host: Chrysemys picta ( 1 in 1 host).

Site: Small intestine.

Specimen: 1, Univ. Neb. State Mus., H. W. Manter Lab. No. 20230.

This is the first report of $P$. angustus from Nebraska. Brooks and Mayes (1975) erroneously cited Barker and Covey (1911) as reporting $P$. angustus from Nebraska; their specimens were in fact from Chrysemys picta in Minnesota.

\section{SPIRORCHIIDAE Stunkard 1921}

\section{Hapalorhynchus stunkardi Byrd 1939}

Host: Chelydra serpentina L. (4 worms in 1 host).

Site: Blood vessels of lungs.

Specimens: 2, Univ. Neb. State Mus., H. W. Manter Lab. No. 20217.

Byrd (1939) described $H$. stunkardi from the blood vessels of the lungs of Kinosternon (= Sternothaerus) carinatum (Gray) in Tennessee. Since this is the first report of the species since its description, both the host and locality are new.

Stunkard (1923) erected the genus Hapalorhynchus for $\mathrm{H}$. gracilis from Chelydra serpentina, stating that there was no cirrus sac or cirrus present. Mehra (1933) erected the genus Coeuritrema for C. lyssemus and C. odhnerensis, stating that they were generically different from $H$. gracilis because they possessed well-developed cirri. Thapar (1933) erected the genus Tremarhynchus for $T$. indicus, but Mehra (1934) pointed out that $T$. indicus possesses a rudimentary cirrus and thus belongs in Coeuritrema. Price (1934) considered Tremarhynchus a synonym of Hapalorhynchus, and Byrd (1939) considered both Tremarhynchus and Coeuritrema synonyms of Hapalorhynchus. Skrjabin (1951) and Yamaguti $(1958,1971)$ both considered Coeuritrema and Hapalorhynchus separate genera. Our specimens and the original description of Hapalorhynchus stunkardi both show a welldeveloped cirrus. Additionally, Brooks and Mayes (1975) described Hapalorhynchus foliorchis and reported a weakly muscular ductus ejaculatorius leading from the seminal vesicle to the genital pore; examination of the holotype 
of $H$. gracilis revealed a similar morphology as did Thapar's description of Tremarhynchus indicus. Since a weakly-muscular ductus ejaculatorius may be termed a rudimentary or poorly-develop cirrus, the synonymy of Coeuritrema and Tremarhynchus with Hapalorhynchus is justified, and the generic diagnosis is hereby emended for the first time to include species with either a well-developed or poorlydeveloped cirrus.

Byrd (1939) compiled a key to the species of Hapalorhynchus, and based his first couplet on the presence or absence of a body constriction at the level of the acetabulum. He descriped $H$. stunkardi as lacking such a constriction, but our specimens of $H$. stunkardi (which were fixed without pressure) have the constriction. The diagnosis of $H$. stunkardi is hereby emended to include such a constriction and the use of the presence or absence of such a constriction for distinguishing species eliminated. We have prepared the following new key to the species of Hapalorhynchus in light of the new morphological information.

Key to Species of Hapalorhynchus Stunkard 1923 Synonyms: Coeuritrema Mehra 1933; Tremarhynchus Thapar 1933

1a. Cirrus welldeveloped

1b. Cirrus poorly developed

2a. Testes smooth

2b. Testes lobed

3a. Esophageal diverticula present

3b. Esophageal diverticula absent

4a. Ovary lobed

4b. Ovary smooth

5a. Vitelline follicles extending into forebody

5b. Vitelline follicles not extending into forebody

6a. Oral sucker smaller than acetabulum

6b. Oral sucker larger than acetabulum

7a. Testes lobed, vitelline follicles extending to bifurcation

lyssemus (Mehra 1933) Byrd 1939

gracilis Stunkard 1923 indicus (Thapar 1933)

Price 1934

foliorchis Brooks and

Mayes 1975

$\quad 7$
odhnerensis (Mehra 1933)
Byrd 1939

odhnerensis (Mehra 1933)
Byrd 1939

Testes smooth, vitel-

line follicles not extending to bifurcation

yoshidai Ozaki 1939

\section{8}

8a. Ovary a narrow transverse band

8b. Ovary ovoid

reelfooti Byrd 1939

stunkardi Byrd 1939

\section{Spirorchis scripta Stunkard 1923}

Host: Chrysemys picta Schneider (5 in 1 host).

Site: Cranial cavity, blood vessels of heart.

Specimens: 3, Univ. Neb. State Mus., H. W. Manter Lab. No. 20214.

The specimens collected in Nebraska are uniformly larger than any previously reported. The body is 1.9 to $2.37 \mathrm{~mm}$ long by 0.34 to 0.47 $\mathrm{mm}$ wide; the oral sucker is 89 to 113 long by 57 to 65 wide; and the eggs are 41 to 65 long by 34 to 57 wide. The anterior testis in all specimens is immediately postbifurcal, a configuration unique to S. scripta. Nebraska is a new locality for the species.

\section{Spirorchis parvus Stunkard 1923}

Host: Chrysemys picta ( 1 in 1 host).

Site: Mesenteric blood vessels.

Specimen: 1, Univ. Neb. State Mus., H. W. Manter Lab. No. 20223.

This is the only known species of Spirorchis with five testes, and the single specimen was easily identified on that basis. Nebraska is a new locality.

\section{PLAGIORCHIIDAE Luhe 1901 \\ Eustomos chelydrae MacCallum 1921}

Host: Chrysemys picta (12 in 1 host).

Site: Small intestine.

Specimens: 8, Univ. Neb. State Mus., H. W. Manter Lab. No. 20224.

MacCallum (1921) described E. chelydrae from Chelydra serpentina from an undisclosed locality. McMullen (1935) redescribed $E$. chelydrae and reported its life cycle from material collected from Chrysemys picta and Chelydra serpentina from Michigan. Guilford (1959) reported E. chelydrae from the same hosts in Wisconsin. Esch and Gibbons (1967) reported it from Chrysemys picta marginata Agassiz in Michigan; Gibbons and Esch (1971) reported it from Sternothaerus m. minor from Florida. Nebraska is a new locality.

HERONIMIDAE Ward 1917 Heronimus mollis (Leidy 1856) Stunkard 1964

Host: Graptemys pseudogeographica (10 in 1 host), new host.

Site: Lungs. 
Specimens: 5, Univ. Neb. State Mus., H. W. Manter Lab. No. 20218.

This is the first report of $H$. mollis from G. pseudogeographica. Brooks and Mayes (1975) reported H. mollis from Chrysemys picta, Chelydra serpentina, and Emydoidea blandingi. Our statement that the first report of the species from Nebraska was by Barker and Parsons (1914) was in error, since Barker and Parson's report was from Chelydra serpentina in Iowa.

\section{ACKNOWLEDGMENTS}

The authors express appreciation to Dr. John D. Lynch, University of Nebraska-Lincoln for host identification; and Mrs. Mary H. Pritchard, University of Nebraska State Museum for her aid in the preparation of the manuscript.

\section{LITERATURE CITED}

Barker, F. D., And G. W. Covey. 1911. A new species of trematode from the painted terrapin, Chrysemys marginata Agassiz. Univ Studies, Univ Neb 11: 193-218.

— monostome from the painted terrapin, Chrysemys marginata. Zool Anzeig 45: 193-194.

Brooks, D. R., AND M. A. MaYes. 1975. Platyhelminths of Nebraska turtles with descriptions of two new species of spirorchiids (Trematoda: Spirorchiidae). J Parasitol 61: 403406.

Byrd, E. E. 1939. Studies on the blood flukes of the family Spirorchidae. Part II. Revision of the family and description of new species. J Tenn Acad Sci 14: 116-161.

Esch, G. W., AND J. W. GibBons. 1967. Seasonal incidence of parasitism in the painted turtle, Chrysemys picta marginata Agassiz. J Parasitol 53: 818-821.

Gibbons, J. W., And G. W. Esch. 1971. Some intestinal parasites of the loggerhead musk turtle (Sternothaerus m. minor). J Herpetol 4: $79-80$.
GuILFORD, H. G. 1959. Some helminth parasites found in turtles from northeastern Wisconsin. Trans Wis Acad Sci, Arts, Lett 48: 121-124.

MacCallum, W. G. 1921. Studies in Helminthology. Part 1. Trematodes. Part 2. Cestodes. Part 3. Nematodes. Zoopathol 1: 135284.

McMullen, D. B. 1935. The life cycle and discussion of the systematics of the turtle trematode Eustomos chelydrae. J Parasitol 21: 5253.

Merra, H. R. 1933. New blood flukes of the family Spirorchidae Stunkard from Indian freshwater tortoises with discussion on the systematic position of the genus Coeuritrema n.g. and the relationships of the families of blood flukes. Part I. Bull Acad Sci U P Agra and Oudh 2 : 203-222.

MehrA, H. R. 1934. New blood flukes of the family Spirorchidae Stunkard from Indian freshwater tortoises with discussion on the synonymy of certain genera and relationships of the families of blood flukes. Bull Acad Sci U P Agra and Oudh 3 : 169-195.

Perkins, M. G. L. 1928. A review of the telorchiinae, a group of distomid trematodes. Parasitology 20: 336-356.

Price, E. W. 1934. New genera and species of blood flukes from a marine turtle with a key to the family Spirorchidae. J Wash Acad Sci 24: 132-141.

SkrJABIN, K. I. 1951. The Trematodes of Animals and Man. Vol. 5: $624 \mathrm{p}$.

Stunkard, H. W. 1923. Studies on North American blood flukes. Bull Am Mus Nat Hist 48: 165-221.

Thapar, G. S. 1933. A new blood fluke from an Indian tortoise, Trionyx gangeticus. J Helm 11: 163-168.

WATERTOR, J. L. 1967. Intraspecific variation of adult Telorchis bonnerensis (Trematoda: Telorchiidae) in amphibian and reptilian hosts. J Parasitol 53 : 962-968.

Yamaguti, S. 1958. Systema Helminthum. Vol. I. The Digenetic Trematodes of Vertebrates. Part 1. Intersci Publ, New York, 979 p. . 1971. Synopsis of Digenetic Trematodes of Vertebrates. Keigaku Publ Co, Tokyo, $1772 \mathrm{p}$ 